\title{
Transcriptional Regulation by the NFAT Family in Acute Myeloid Leukaemia
}

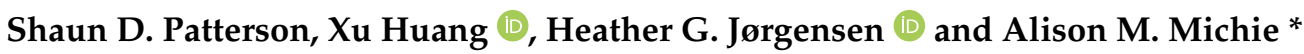 \\ Paul O'Gorman Leukaemia Research Centre, Institute of Cancer Sciences, College of MVLS, \\ University of Glasgow, Glasgow G120ZD, UK; s.patterson.1@research.gla.ac.uk (S.D.P.); \\ Xu.Huang@glasgow.ac.uk (X.H.); Heather.Jorgensen@glasgow.ac.uk (H.G.J.) \\ * Correspondence: Alison.Michie@glasgow.ac.uk; Tel.: +44-(0)141-301-7885
}

Citation: Patterson, S.D.; Huang, X.; Jørgensen, H.G.; Michie, A.M.

Transcriptional Regulation by the NFAT Family in Acute Myeloid Leukaemia. Hemato 2021, 2, 556-571. https://doi.org/10.3390/ hemato2030035

Academic Editors: Ugo Testa and Roland B. Walter

Received: 14 July 2021

Accepted: 23 August 2021

Published: 27 August 2021

Publisher's Note: MDPI stays neutral with regard to jurisdictional claims in published maps and institutional affiliations.

Copyright: (c) 2021 by the authors. Licensee MDPI, Basel, Switzerland. This article is an open access article distributed under the terms and conditions of the Creative Commons Attribution (CC BY) license (https:/ / creativecommons.org/licenses/by/ $4.0 /)$.

\begin{abstract}
Acute myeloid leukaemia (AML) is a haematological cancer with poor outcomes due to a lack of efficacious targeted therapies. The Nuclear Factor of Activated T Cells (NFAT) family of transcription factors is well characterised as a regulator of the cell cycle and differentiation in the myeloid lineage. Recent evidence has demonstrated that NFAT family members may have roles in regulating AML leukemogenesis and resistance to targeted therapy in myeloid leukaemia. Furthermore, gene expression data from patient samples show that some NFATs are more highly expressed in poorly differentiated AML and after disease relapse, implying that the NFAT family may have roles in specific types of AML. This review outlines the evidence for the role of NFAT in healthy myeloid tissue and explores how NFAT might regulate AML pathogenesis, highlighting the potential to target specific NFAT proteins therapeutically in AML.
\end{abstract}

Keywords: leukaemia; NFAT; myeloid; cell cycle; differentiation; AML

\section{Introduction}

Acute myeloid leukaemia (AML) is a hematopoietic malignancy of clonal origin with dismal survival outcomes [1]. AML results from an accumulation of mutations within cells of the myeloid lineage, leading to the expansion of immature and dysfunctional blasts, rapid clinical sequelae and often rapid death. Many of the genetic and epigenetic lesions responsible for driving AML pathogenesis are well-characterised, enabling sophisticated patient stratification into molecular subgroups and a shift towards targeted therapies for smaller strata of patients [2,3]. However, intra- and inter-patient molecular heterogeneity and the continuous mutational evolution of AML means that resistance to existing therapy is not uncommon $[4,5]$. The persistence of minimal residual disease after treatment is also attributed to therapy-resistant leukemic stem cells (LSCs), which exhibit distinct phenotypic and genomic properties to the bulk of AML blasts [6-8].

In addition to (cyto)genetic status, the AML transcriptome has been described as a tool for patient prognostication, whereby expression profiles within circulating blasts and/or LSC s can aid in the risk stratification of patients and can reveal specific mechanisms of oncogenesis [9-12]. Transcriptional regulators could be ideal therapeutic targets for AML, such that the effectors of multiple signalling pathways could be targeted simultaneously [13]. In fact, a number of transcription factors with known roles in leukaemia are under investigation as putative drug targets for AML, including RUNX1 and c-MYC [14].

The Nuclear Factor of Activated T Cells (NFAT) family of transcription factors has been demonstrated to have roles in the pathology of myeloid leukaemia $[15,16]$. NFAT signalling has been well-characterised in various solid and lymphoid cancers, in addition to the mechanics of the innate immune system. Their role in pathology is often dependent on regulation of cell type-specific cytokine signalling networks, cell cycle progression and apoptosis [17-20]. This review outlines the functions of NFAT in myeloid tissues and examines current evidence supporting a role for NFAT in AML pathogenesis. 


\section{NFAT Proteins: Structure, Function and Regulation}

The general structure and function of the NFAT family are reviewed extensively elsewhere $[18,21-23]$. To summarise, the NFAT family consists of five members, in which NFATc1-4 function downstream of calcium signalling - denoted as 'NFATc', although other nomenclature is often used-while NFAT5 is responsive to osmotic stress. This review will focus on NFATc1-4, henceforth referred to as 'NFAT' collectively. Additionally, each NFAT gene can undergo alternative splicing, giving rise to a number of transcript and protein variants per family member; these protein variants vary structurally at their $\mathrm{N}$ and C-terminals. Differential expression of NFAT splice variants has been described in neurological tissues, but the functional significance of these is not well understood [24]. Here, each of NFATc1-4 is referred to as an NFAT 'family member', while each protein arising from alternative splicing is a 'protein variant'.

NFAT proteins have high-sequence homology in a conserved DNA-binding Rel homology domain, which is shared with the Rel superfamily of transcription factors (including $\mathrm{NF} \kappa \mathrm{B})$ [25]. At the N-terminus is the NFAT homology domain (NHD), which contains phosphorylation sites that are targeted by upstream regulatory kinases. Critically, this region possesses docking sites for regulatory phosphatase calcineurin, which dephosphorylates most of these phospho-sites. The $\mathrm{N}$ - and $\mathrm{C}$ - termini are flanked by transactivation domains (TADs), which are non-homologous between family members and are a key interaction point with transcriptional partner proteins [24,26]. Figure 1 shows some of the nomenclature (a), protein regions with sequence alignment between differing NFAT family members (b) and alignment amongst protein variants of NFATc2 (c).

\begin{tabular}{|c|c|c|c|}
\hline Name & $\begin{array}{c}\text { Alternative } \\
\text { Name(s) }\end{array}$ & $\begin{array}{c}\text { Number of Known } \\
\text { Protein Variants }\end{array}$ & $\begin{array}{c}\text { Protein Length } \\
\text { (Amino Acids) }\end{array}$ \\
\hline NFATc1 & NFAT2, NFATc & 10 & $353-943$ \\
\hline NFATc2 & NFAT1, NFATp & 6 & $688-917$ \\
\hline NFATc3 & NFAT4, NFATx & 3 & $1065-1075$ \\
\hline NFATc4 & NFAT3 & 9 & $782-965$ \\
\hline
\end{tabular}

(a)

Figure 1. Cont. 


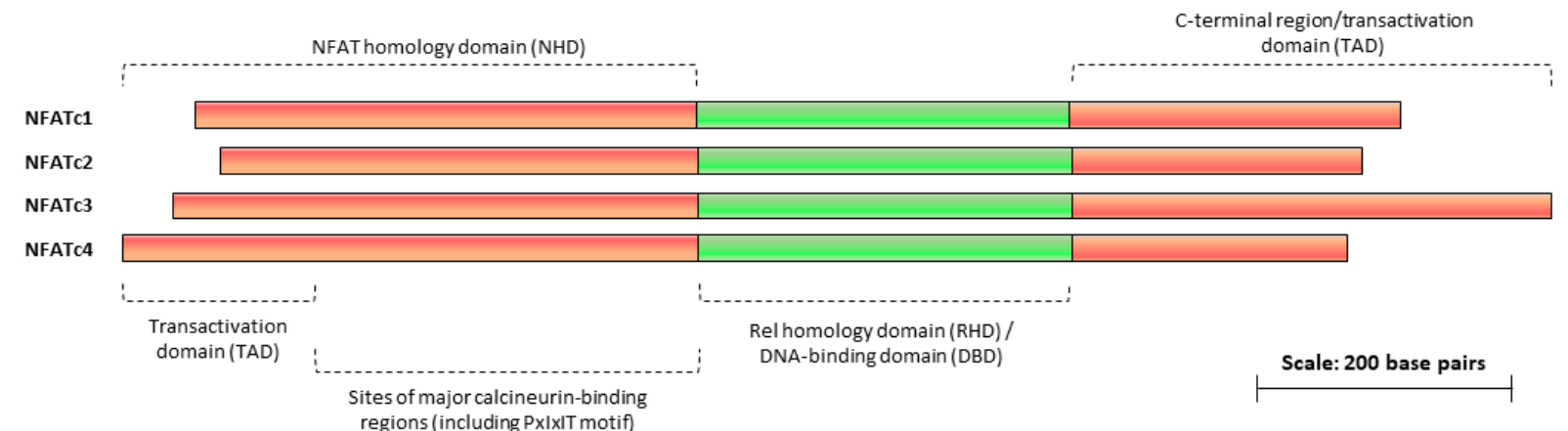

(b)

NFATc2

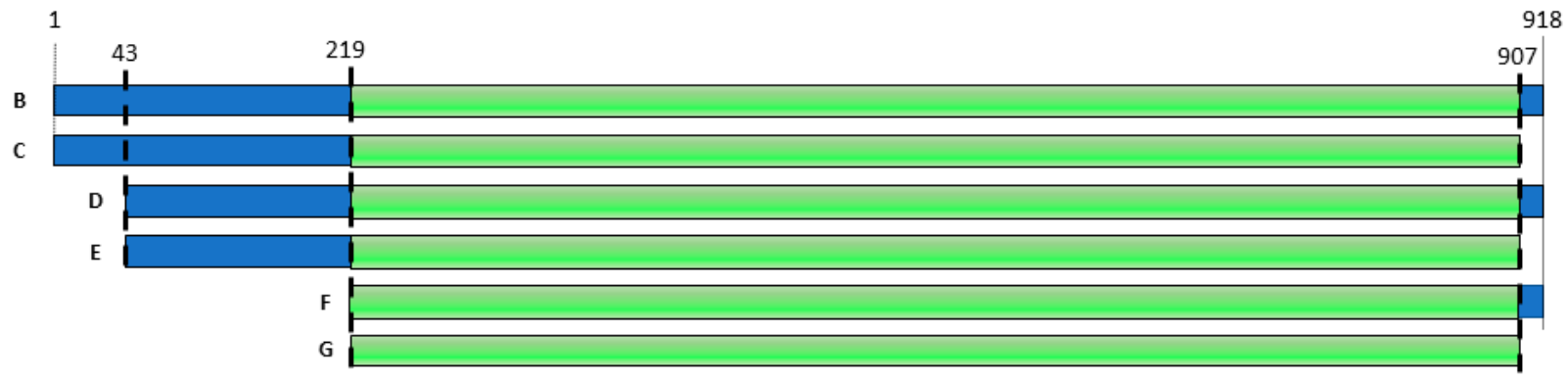

(c)

Figure 1. Nomenclature of NFAT and schematic diagrams of NFAT protein alignment. (a) Table highlighting alternative nomenclature for NFATc1-4. The number of protein variants (as arises from alternative splicing) is highlighted per NFAT family member. The protein length, given in amino acids, is shown as a range from the shortest to longest protein variant, per NFAT family member. These data were extracted from the NCBI database, based on the GRCh38 genome. (b) Protein alignment diagram for NFATc1-4. Protein sequences for each of NFATc1-4, for the longest protein variant per family member, were aligned and scored for strength of alignment using the online PRALINE multiple sequence alignment tool (via Centre for Integrative Bioinformatics VU, University of Amsterdam). Sequences were obtained as in (a). A central region of high-sequence homology was defined at a similar position as in the literature [20] (amino acid position 400-698, relative to NFATc1 in this case, shown in green) and showed a higher mean alignment score amongst all NFATc1-4 than other regions (7.84 for the central homologous region; 3.58 for the N-terminal; 2.64 for the C-terminal; maximum possible score is 10). Highlighted are approximate locations for key functional regions as described in the literature [18,20-23,27]. (c) A schematic diagram showing the protein sequence alignment between protein variants of NFATc2. Sequences were obtained and aligned as in (b). Shown are all six variants ' $B$ '-' $G$ ' with the amino acid position given (relative to variant ' $B$ '). Regions of $100 \%$ sequence homology are shown in green.

Inactive NFAT proteins reside in the cytoplasm in a heavily phosphorylated state. Activation of calcium-coupled surface receptors (e.g., receptor tyrosine kinases) triggers a signalling cascade via phospholipase C (PLC), which promotes calcium influx in a process known as store-operated calcium entry (SOCE). In response to elevated calcium, the messenger calmodulin activates multiple target enzymes, which include calcineurin and calmodulin kinase (CAMK) isoforms. Activated calcineurin docks on NFAT at conserved PxIxIT peptide motifs and subsequently dephosphorylates at up to 14 known serine-rich motifs on the NHD [22,28]. 
The conformational change that follows NFAT dephosphorylation exposes a 'nuclear localisation signal' enabling its nuclear import. The subcellular location of NFAT is carefully balanced by opposing calcineurin phosphatase activity and that of numerous kinases, which mask these localisation signals to facilitate nuclear export in the absence of raised intracellular calcium. Examples of these kinases include GSK3, CK1 and JNK. Additionally, p38 MAPK has been found to regulate NFAT transactivation in the nucleus through phosphorylation at a motif separate to those regulated by calcineurin $[26,29,30]$.

Once inside the nucleus, NFAT binds DNA as a monomer, unlike other Rel superfamily members. The core NFAT DNA consensus binding sequence has been defined as $5^{\prime}$-GGAA(A)-3' in T cells, but variations have been described with differing binding affinities $[23,26,31]$. Lone NFAT DNA binding is often weak and it must bind in tandem with other factors at composite sequences to regulate transcription, as has been shown with AP-1 proteins Fos and Jun [32]. In the case of NFKB proteins, NFAT could either compete with them or bind cooperatively, depending on the DNA motifs [31]. One proteomics study described hundreds of putative NFAT interaction partners in T cells [33], raising the notion that NFAT proteins function as part of large transcriptional complexes and so are master integrators of upstream signalling pathways. A schematic diagram of NFAT function in the cell is shown in Figure 2.

Inhibition of NFAT activation can be achieved by targeting calcineurin, using either of the small molecule inhibitors cyclosporine A (CsA) or tacrolimus. These are both used clinically to prevent graft rejection after organ transplantation, primarily due to the immunosuppressive effects on $\mathrm{T}$ and $\mathrm{B}$ cell activation secondary to inhibited NFATdependent cytokine transcription. While different in structure and target, they both form complexes with cellular immunophilins, which can inhibit calcineurin phosphatase activity [34]. Calcineurin has numerous targets in addition to NFAT [35], making this a relatively non-specific means of inhibiting NFAT activity. Subsequently, a more selective peptide inhibitor 'VIVIT peptide' was developed, which directly binds the calcineurin docking motif PxIxIT on NFAT, thus more selectively inhibiting NFAT activity [36]. These inhibitors are useful tool compounds to study NFAT function. 


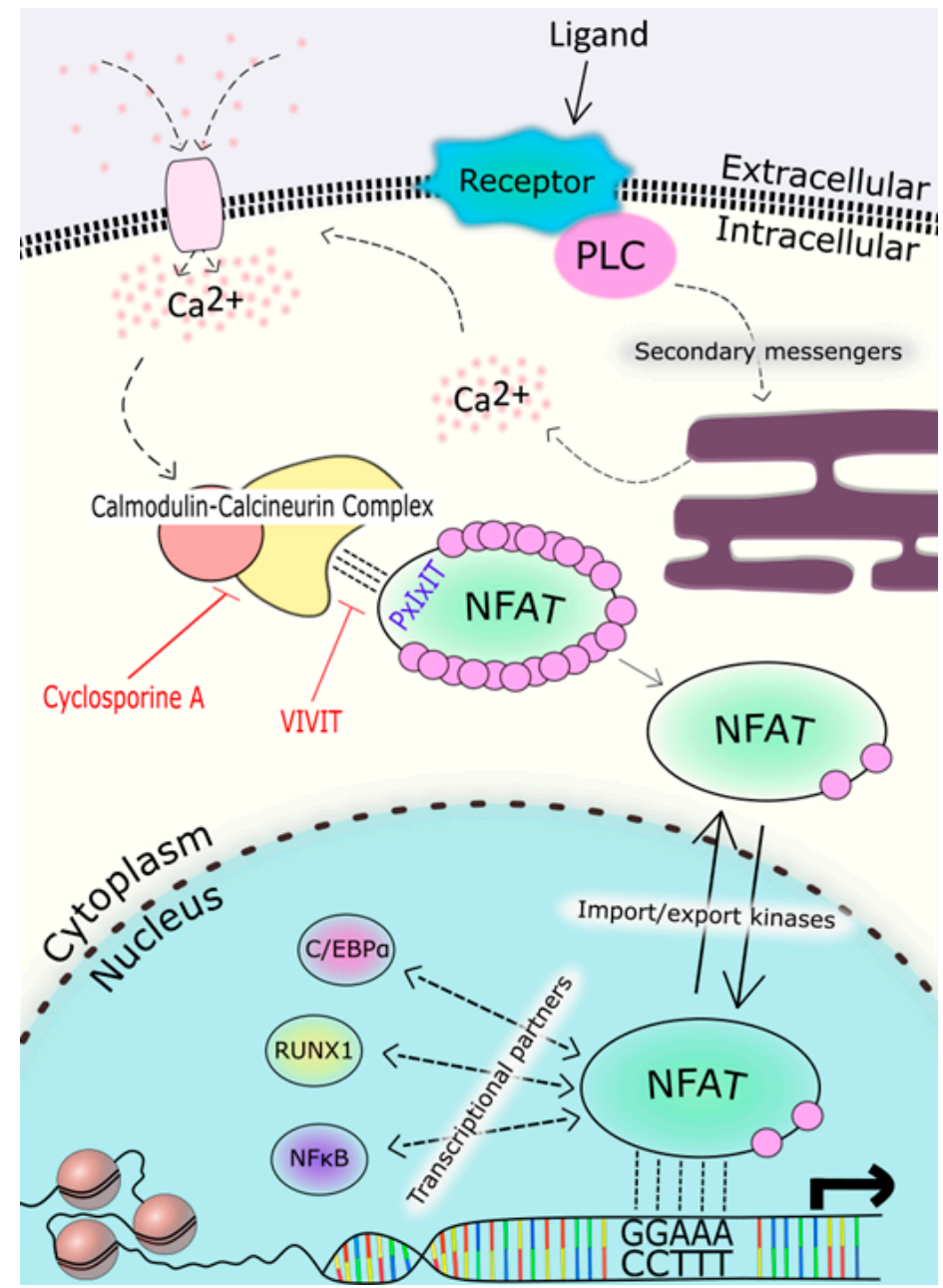

Figure 2. Schematic diagram of calcium-NFAT signalling. 1. Engagement of a calcium-coupled surface receptor by its ligand leads to activation of phospholipase C (PLC). 2. A cascade of signalling events is initiated by PLC, which leads to the movement of calcium from the endoplasmic reticulum (ER) into the cytoplasm. 3. Following the depletion of ER calcium stores, surface calcium releaseactivated calcium (CRAC) channels are opened, enabling an influx of calcium to the cell. 4 . Raised calcium levels trigger activation of calmodulin, which binds calcineurin. 5. A conformational change in calcineurin allows it to bind to NFAT at the PxIxIT docking motif and dephosphorylate NFAT at 14 phospho-sites. 6. Dephosphorylation of NFAT-with the exception of some residues not targeted by calcineurin-exposes a nuclear localisation signal and enables its import to the nucleus. 7 . Once in the nucleus, NFAT can bind to consensus DNA sequences-including 5'-GGAAA-3' —and activate (or inhibit) transcription. It may do so in cooperation with various transcriptional partners, which can include C/EBP $\alpha$, RUNX1 and/or NFKB. NFAT's position in the nucleus is balanced by the activity of import and export kinases. Note that inhibitors cyclosporine A (CsA) and VIVIT peptide can inhibit activation of the calmodulin-calcineurin complex or binding of calcineurin to NFAT, respectively.

\section{NFAT Expression in the Myeloid Lineage}

NFAT expression in differentiated myeloid cells is generally lower than in T cells and $\mathrm{CD}_{3} 4^{+}$hematopoietic stem cells (HSCs). Kiani et al. demonstrated that NFATc1-3, but not NFATc4, are well expressed in CD34 $4^{+}$blood cells and altered within myeloid lineages. NFATc2 is downregulated in most differentiated myeloid cells, while NFATc1 is upregulated during the course of erythroid and megakaryocyte differentiation. NFATc3 is upregulated during erythroid but not megakaryocyte or eosinophil differentiation. Furthermore, inhibition of calcineurin-NFAT signalling with CsA was found to be permissive of $\mathrm{CD} 34^{+}$HSC differentiation into neutrophils $[37,38]$. These data suggest that NFATs 
are responsible for regulating differentiation in healthy cells and that the NFAT family members are non-redundant in determining cell fate. This also suggests that specific NFAT members could be more important in the development of some morphological subtypes of AML.

Supporting these in vitro findings, a gene expression analysis of NFATC1-4 from $\mathrm{CD}_{4} 4^{+}$and differentiated blood cells from healthy adults showed that mature granulocytes and monocytes exhibit lower expression of NFATC1-3 than cells of a lymphoid origin or more primitive CD34 ${ }^{+}$cells (GSE51984 dataset; Figure 3a-c)). NFATC2 is poorly expressed in differentiated myeloid cells relative to NFATC1 and NFATC3, suggesting that it has a diminished role in these mature cells. NFATC4 expression was barely detectable in any lineage or $\mathrm{CD}^{+} 4^{+}$cells $(\mathrm{RPKM}<1$; data not shown).

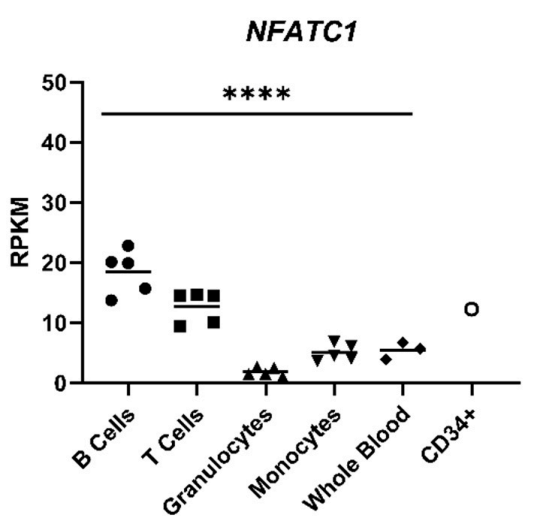

(a)

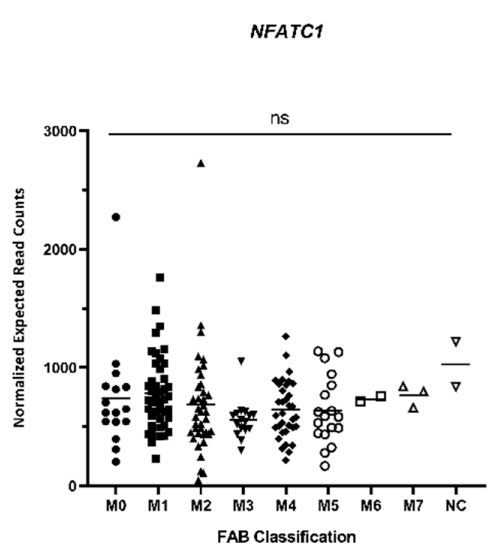

(d)

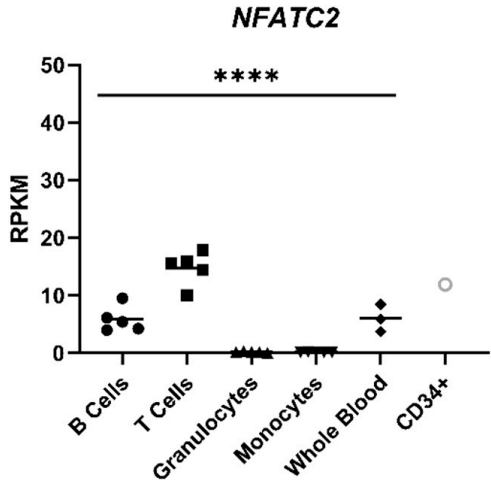

(b)

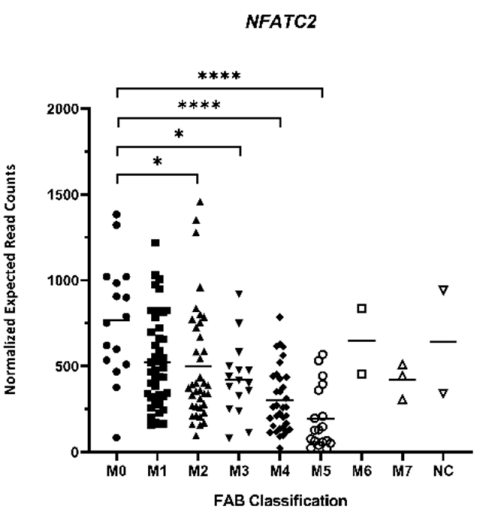

(e)

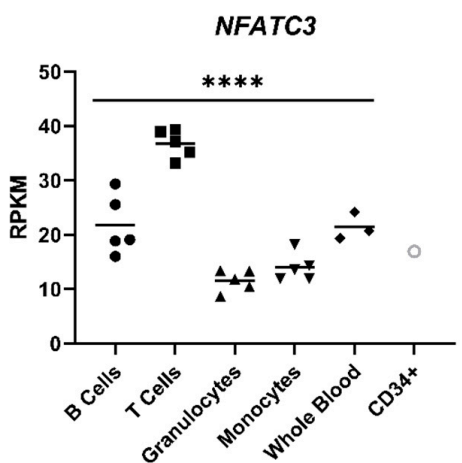

(c)

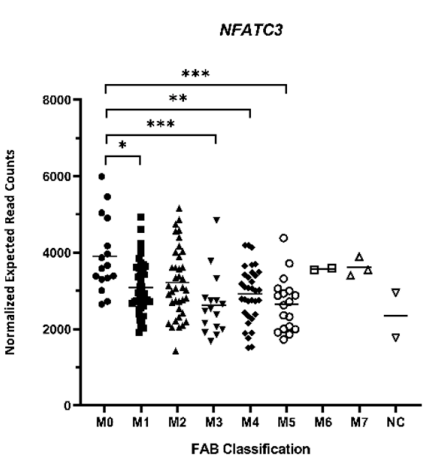

(f)

Figure 3. Differential expression patterns of NFAT family members in normal and leukemic myeloid cells. (a-c) RNA-seq data were generated by Pabst et al. from the peripheral blood of healthy volunteers for expression of NFATC1-3 (GEO repository ID GSE51984 [39]). Cells were sorted based on expression of the following surface markers: CD34, CD3 (T cells), CD19 (B cells), CD14 (monocytes) and CD33 (granulocytes). Each data point represents an individual, except for CD34 ${ }^{+}$, where the data point is an average of four individuals. Normalised expression values are presented as RPKM and $p$-values from a one-way ANOVA for a difference in mean (excluding CD34 data) are shown $\left.{ }^{* * * *} p<0.0001\right)$; (d-f). RNA-seq data were obtained from the Cancer Genome Atlas (TCGA) AML dataset [40]. Data were extracted using the TCGAbiolinks R package ( $\mathrm{R}$ v4.0.0), for 173 adult patients with de novo AML for the expression of NFATC1-3 in AML tissue and annotated by disease FAB classification. NC = 'not classified'. Expression values are 'normalised expected read counts' derived from the RSEM method [41]. Dunnett's post hoc test (following one-way ANOVA) $p$-values for a difference in mean are shown $\left({ }^{*} p<0.05 ;{ }^{* *} p<0.01 ;{ }^{* * *} p<0.001 ;{ }^{* * *} p<0.0001\right)$. 
AML cells are characteristically poorly differentiated [42] and it is worth considering whether NFAT could have a role in maintaining the stem cell-like properties of blasts, given the observed gene expression profiles in healthy myeloid tissue. RNA-seq data for NFAT expression were extracted from the TCGA dataset of 173 adults with de novo AML [40] (Figure $3 \mathrm{~d}-\mathrm{f}$ ). These were categorised according to the French-American-British (FAB) classification based on AML blast morphology [43], which gives a broad understanding of the differentiation status of blasts (classification described in Appendix A). These data show that poorly differentiated myeloid leukaemia, particularly in type M0, have a significantly higher expression of NFATC2 and NFATC3 than more differentiated forms of AML. In contrast NFATC1 expression appears consistent regardless of FAB subtype. It could be hypothesised that NFATC2 and/or NFATC3 negatively regulate differentiation pathways in AML and so warrant further investigation to determine the mechanism(s).

\section{The Role of NFAT in Myeloid Cells}

NFAT proteins regulate genes that determine the proliferation and lineage commitment in the myeloid lineage. In murine granulocyte-monocyte progenitor (GMP) cells, NFAT was found to negatively regulate genes that determine cell cycle entry such as Cdk4 and Cdk6. This activity was dependent on the Flt3 ligand (Flt3-L) signalling and phospholipase PLC $\gamma 1$-dependent calcium influx [44]. Another study found that CsA inhibition of Flt3-L-stimulated murine dendritic cells (DCs) led to the upregulation of genes that progress the cell cycle, suggesting that targets of calcineurin block Flt3 receptor-mediated cycling. Additionally, the blockade of the calcineurin-NFAT interaction with VIVIT also led to the expansion of the myeloid compartment in vivo [45]. These studies suggest that the NFAT proteins inhibit proliferative signalling in myeloid development and interact with FLT3 receptor signalling.

In normal physiology, the growth factors known as the macrophage- and granulocyte colony-stimulating factor (M-CSF and G-CSF) trigger HSCs to differentiate into either macrophages/monocytes or granulocytes, respectively. Nfatc1 expression was found to increase in murine bone marrow cultures stimulated with M-CSF, but not G-CSF. Differentiation triggered by M-CSF was partially blocked by VIVIT, suggesting that it is dependent on the calcineurin-NFAT interaction. Furthermore, distinct from the Flt3-L-stimulated GMPs described above, stimulation with either M-CSF or G-CSF was found to induce PLC $\gamma 2$ (but not PLC $\gamma 1$ ) activity [46]. Therefore, it appears that the regulatory function of NFAT in myelopoiesis, in the balance of proliferation and differentiation, is dependent on specific upstream signalling networks.

NFAT proteins are well characterised in the $\mathrm{T}$ cell effector function and also play a role in the myeloid cell response to pathogens. Pattern recognition receptors (PRRs), such as TLR4, respond to structural elements of invading microbes to trigger an immune response. Engagement of PRRs in a number of differentiated myeloid cell types can stimulate the calcineurin-NFAT interaction via calcium influx initiated by Syk and PLC $\gamma$ [47]. NFAT can also bind the canonical $5^{\prime}$-GGAAA- $3^{\prime}$ DNA motif and regulate the expression of various cytokines in dendritic cells and macrophages, including IL-2, IL-10 and IL-12, which influence immune responses $[48,49]$. There is limited evidence suggesting that systemic CsA treatment in transplant patients could worsen outcomes due to a greater risk of fungal infection, secondary to the inhibition of myeloid effector cell function, specifically [47]. Some of these roles of NFATs are shown schematically in Figure 4. 


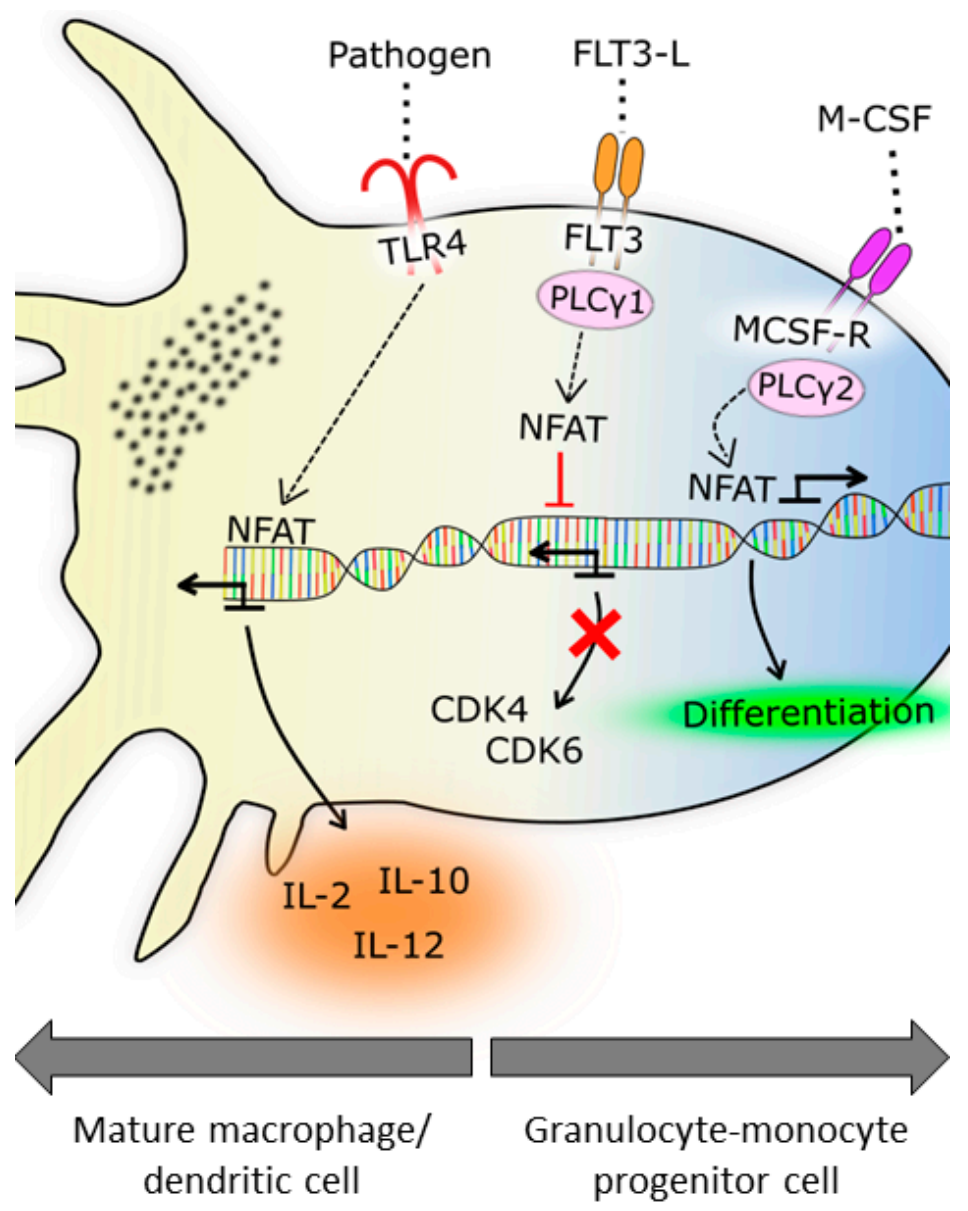

Figure 4. Schematic diagram of putative roles for NFAT in myeloid lineage cells. Roles for NFAT inferred from aforementioned studies [44-49] are shown as putative roles in human myeloid cells, schematically as a myeloid cell in different 'stages' of differentiation. Left: in mature dendritic cells, pathogens trigger pattern recognition receptors (PRRs) such as TLR4, which is thought to be upstream of NFAT-driven cytokine transcription. Middle: in progenitor cells, NFAT is downstream of a FLT3-PLC $\gamma 1$ axis, whereby it inhibits regulators of the cell cycle. NFAT may also act downstream of FLT3 in dendritic cells. Right: in granulocyte-monocyte progenitors (GMPs), NFAT activates myeloid differentiation in response to M-CSF receptor engagement, which also signals via PLC $\gamma 2$.

The evidence discussed highlights that NFAT activity can direct myeloid progenitors towards quiescence by inhibiting the cell cycle or favour differentiation, depending on the specific upstream pathways activated. Leukemic transformation to AML is dependent on deregulation of these processes in steady state myelopoiesis and these changes are often promoted through transcription factors [42]. As such, NFAT proteins could influence AML initiation or maintenance downstream of mutated signalling proteins. For example, the FLT3 receptor is commonly mutated in AML, leading to enhanced proliferation. Understanding the relationship between FLT3-L and NFAT activity in healthy myeloid cells could therefore provide insight into this relationship in leukaemia. In parallel, TLR4 participates in HSC regulation and is overexpressed in some types of AML [50,51], so it is worth considering whether a TLR-NFAT axis is as important in oncogenesis as in mature myeloid cell function.

Broadly speaking, NFAT proteins have a greater role in less differentiated myeloid cells (Figure 3) and might also be important in the differentiation status of AML. It could also be inferred that each family member is non-redundant, so further investigation into individual roles is warranted. Ultimately, given the distorted nature of the hematopoietic hierarchy in AML [7] these are only inferences from healthy cells and should be examined more closely in leukaemia tissue. 


\section{NFAT Signalling in AML}

There is growing evidence that NFAT signalling cooperates with mutations of the Fmsrelated tyrosine kinase receptor 3 (FLT3) receptor in AML. Internal tandem duplication of the FLT3 receptor (FLT3 ${ }^{\mathrm{ITD}}$ ) is present in around $25 \%$ of AML cases and confers particularly poor outcomes for patients compared to other AML subtypes [52]. This is a gain-of-function mutation that causes ligand-independent proliferative signalling [53].

Exogenous expression of $F l t 3^{I T D} / F L T 3^{I T D}$ in hematopoietic cells has been shown to induce a myeloproliferative disease and it is understood to require other driver mutations to induce overt AML $[54,55]$. In one of these models' co-expression of Flt3 ${ }^{I T D}$ with a constitutively active form of human NFATC1 led to the rapid development of myeloid leukaemia and expansion of immature blasts in vivo. Interestingly, the expression of constitutive NFATC1 alone inhibited the colony-forming capacity of sorted $\mathrm{Lin}^{-} \mathrm{Sca}^{+} \mathrm{c}-\mathrm{kit}^{+}$ (LSK) bone marrow cells, but Flt3 ${ }^{I T D}$ co-expression increased colony formation dramatically, more than Flt3 ${ }^{I T D}$ alone [54].

The observed phenotypes imply that NFATc1 has an inhibitory effect on expansion of primitive LSK cells, in parallel to the studies conducted in GMPs [44,45]. Constitutively active FLT3 signalling appears to supersede this and the cooperativity with NFAT induces a distinct transcriptional program permissive of AML development [54]. Signalling downstream of FLT3 ${ }^{\mathrm{ITD}}$ is different from that of the normal FLT3 receptor, as has been demonstrated in murine hematopoietic cells with aberrant activation of STAT5 [56]. One possibility is that the engagement of pathological signalling by FLT3 ${ }^{\text {ITD }}$ may influence the recruitment of other factors to transcriptional complexes containing NFATc1. However, this model is an artificial representation of AML and does not reflect on the true ontogeny of leukaemia. Evidence from relapsed AML patients suggests that FLT3 ${ }^{\mathrm{ITD}}$ often arises as a later event and is not consistently found in the founding LSC clone [57], which should be kept in mind when considering NFAT as an effective therapeutic target.

NFATc1 activity can also mediate resistance to tyrosine kinase inhibitors (TKIs). FLT3 ${ }^{\text {ITD }}$ AML can be treated with TKIs such as sorafenib and quizartinib, but point mutations and/or 'escape' signalling pathways often lead to resistance and relapse [58]. Metzelder et al. demonstrated that the depletion of NFATC1 by shRNA or NFATc1 functional inhibition with CsA or VIVIT treatment could increase sensitivity of FLT3 ${ }^{\text {ITD }}$ AML cells to sorafenib. Expression of a constitutively nuclear NFATc1 with FLT3 ${ }^{\text {ITD }}$ in myeloid progenitor cells increased resistance to sorafenib and also induced morphological signs of de-differentiation [15]. It is not clear whether NFATc1 and FLT3 ${ }^{\text {ITD }}$ cooperativity activate a specific resistance mechanism, which permits FLT3 ${ }^{\mathrm{ITD}}$ blasts to escape sorafenib-mediated cell death. The reversal of cell maturation may also highlight a pathogenic role of NFATc1 in maintaining stem cell-like properties, akin to the high expression of NFATc1-3 observed in in normal HSCs [37,38].

Resistance to TKIs in chronic myeloid leukaemia (CML) was also found to be linked to NFAT activity. CML is characterised by the $B C R / A B L$ fusion oncogene, which is effectively targeted by the TKI imatinib. As with FLT3 inhibitors, resistance to imatinib can arise through a number of mechanisms, including $B C R / A B L$ mutations and receptor-independent means [59]. Gregory et al. identified NFAT-stimulated autocrine IL-4 signalling as a mechanism of imatinib resistance and the effect was modulated primarily by NFATc1 [16]. IL-4 is an established regulatory target of NFAT in the function of various immune cells [17]. Sung et al. found that AML cells can increase resistance to FLT3 ${ }^{\text {ITD }}$ inhibition by autocrine stimulation with various cytokines, including IL-6 and GM-CSF, which are also targets of NFAT in some myeloid lineage cells $[17,60]$. Based on the evidence available, investigation into the role of NFAT in autocrine cytokine signalling in AML may yield further insight into the mechanism(s) of resistance to FLT3 inhibitors.

Resistance to therapy, be it FLT3 inhibitors or otherwise, is a common cause of relapse in AML [61], with evidence so far focusing on TKIs and FLT3 ${ }^{\text {ITD }}$ AML. To investigate whether NFAT might be important in AML relapse following chemotherapy, RNA-seq data were extracted from the GSE83533 dataset, which is derived from paired patient samples 
$(n=19)$ at diagnosis and at relapse. All patients were initially treated with combination chemotherapy, in some cases followed by stem cell transplantation [62]. The expression of NFATC2 and NFATC 3 was significantly higher in relapse samples, while NFATC1 expression was unchanged (Figure 5). As these were paired samples, this suggests there could be outgrowth of NFATC2/3 high chemo-resistant clone(s) following initial therapy, or that NFATc2/3-driven signalling is recruited secondary to acquired resistance mechanisms.

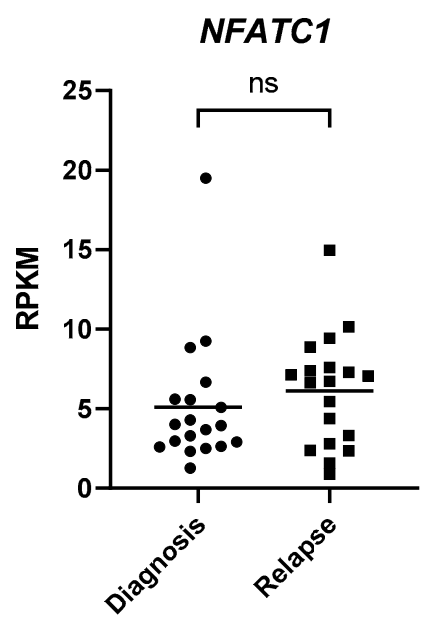

(a)

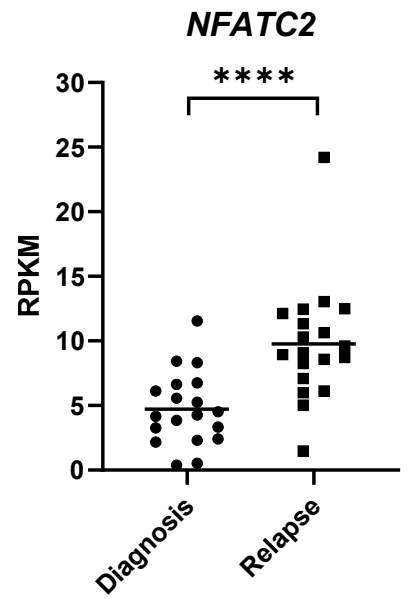

(b)

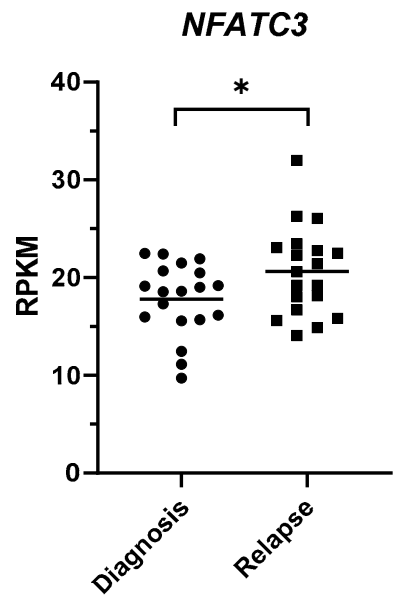

(c)

Figure 5. NFAT expression in AML patients at diagnosis and relapse. (a-c) RNA-seq data were generated by Li et al. from samples derived from patients with AML $(n=19)$ at diagnosis and relapse, following a standard treatment protocol. Normalised expression data for NFATC1-3 are shown as RPKM from diagnosis and relapsed samples. Wilcoxon matchedpairs signed-rank test $p$-values, for a difference in medians, are shown $\left({ }^{*} p<0.05\right.$; $\left.{ }^{* * *} p<0.0001\right)$.

Chemotherapy primarily targets cycling cells and so is often evaded in AML by subclones that are more quiescent and / or plastic in their state of differentiation, like the LSC population. However, the ability of the LSCs to persist through treatment and regenerate AML blasts is highly multi-dimensional, depending on the interaction of epigenetic and transcriptional regulators, the evasion of the immune response and the interaction with the bone marrow microenvironment $[61,63]$. The evidence discussed shows that NFAT can regulate cycle genes and stem cell properties in myeloid physiology and pathology, and so could plausibly have roles in mediating chemotherapy resistance or LSC development, but its precise role in this complex interplay is not yet clear.

The role of NFAT transcriptional partners may aid the generation of a more complete picture of the active regulatory networks in AML. For example, RUNX1 may cooperate with $\mathrm{FLT}^{\mathrm{ITD}}$ in the development of AML [64] and is also known to regulate key oncogenes, such as p53 [14]. RUNX1 somatic mutations and chromosomal translocations are well characterised in AML [65]. Masuda et al. demonstrated that RUNX proteins regulate NFATC2 transcription and this was inhibited by the RUNX inhibitor Chb-M' in their models of AML, particularly in acute promyelocytic leukaemia (APL) [66], suggesting that NFATC2 could play a role in the mechanism of RUNX-driven oncogenesis here. NFAT was also found to interact with the promyelocytic leukaemia (PML) protein-a tumour suppressor frequently disrupted in APL—in fibroblasts [67,68]. Further investigation of these transcriptional partners may also highlight a novel role for NFAT in APL pathogenesis. Various other transcriptional partners of NFAT are known to be deregulated in AML, such as AP-1 proteins $[69,70]$ and $\mathrm{C} / \mathrm{EBP} \alpha[71]$, although their intrinsic involvement with NFAT has not been demonstrated in this context. A focused investigation into their relationship with NFAT in AML may yield novel mechanisms of action and/or means of targeting NFAT activity. 
At present, there is a lack of evidence around whether NFAT proteins mediate leukaemia initiation or participate in maintenance in tandem with other mutational drivers. Existing models focus on FLT3 ${ }^{\mathrm{ITD}}$-driven signalling and are based primarily on synthetic models of AML, which do not necessarily reflect the complex clonal architecture or molecular heterogeneity of de novo leukemogenesis. Additionally, most studies present evidence for NFATc1 activity or are based on inhibition of all NFAT or calcineurin activity, in the absence of more specific compounds. Evidence from solid tumours suggests that individual members of the NFAT family have distinct and sometimes opposing roles in regulation of the cell cycle [20]. Together with the differential expression profiles of NFATC1-3 presented in this review, it is reasonable to postulate that each NFAT family member may contribute differentially to AML pathogenesis, and should be investigated as such. It should also be noted that functional variants of NFAT genes are not commonly found, although not absent, as shown by mutational profiling of large AML patient datasets [5,40]. In light of the evidence available, there are some considerations for future therapeutic strategies to target NFAT signalling in AML.

\section{Therapeutic Targeting of NFAT Proteins}

Cyclosporine A, tacrolimus and VIVIT peptides have served as key inhibitors for experimental research into NFAT, but their clinical application is quite limited. Calcineurin, the target of CsA, has a number of targets other than NFAT that are less well characterised [35]. The clinical use of CsA in organ transplant patients is associated with significant nephrotoxicity and neurotoxicity, due to some of these other targets and the role of NFAT proteins in the nervous and cardiovascular systems [72]. Tacrolimus has an even higher toxicity, but some evidence suggests that lower doses could be well-tolerated by patients [73,74], though this would still carry the issue of non-specificity towards NFAT. CsA is also known to inhibit P-glycoprotein (Pgp), which can increase cellular efflux of some chemotherapeutics and reduce their efficacy. One randomised controlled trial of patients with poor risk AML ( $n=226)$ found that intravenous CsA treatment improved overall survival, although this was linked with inhibition of Pgp and thus potentially not connected to NFAT activity [75]. However, highly toxic chemotherapy regimens are not well tolerated by cohorts of older AML patients, so more targeted drugs would be advantageous.

VIVIT has the advantage of targeting the calcineurin-NFAT interaction specifically. It has been developed to be cell permeable, stable in the circulation (half-life $=30 \mathrm{~h}$ ) and is capable of inhibiting $\mathrm{T}$ cell function in mice [76]. There is currently no clinical data regarding VIVIT; however, some in vivo data in cardiovascular disease models suggest that its pharmacological properties are undesirable for application to patients [77]. There are various experimental compounds that target other elements of NFAT function. The salicylic acid derivative UR-1505 specifically blocks NFAT binding to DNA and was found to be an effective immunosuppressant [78], but its efficacy translated poorly to the clinic as a dermatitis therapy, particularly when compared with tacrolimus [79]. Based on extremely limited clinical information, there is clearly a need to develop NFAT-targeted therapy further in order to progress research into its viability.

Additionally, recent research has identified novel means of targeting specific NFAT family members. A novel calcineurin-binding region (CNBR) is present in the N-terminus of some NFATs, while other binding regions have variable binding affinities for calcineurin between NFATc1-4, meaning that it could be possible to preferentially target some of the NFAT family members therapeutically. For example, it may be possible to specifically inhibit the interaction of calcineurin with either NFATc1 and NFATc4 by targeting CNBR3, but no such inhibitor exists presently [27]. More broadly, therapeutic targeting of transcription factors has been shown to be challenging, although inhibitors of the related Rel protein NF- $\mathrm{KB}$ are in early clinical trials for the treatment of AML and other cancers [80]. Some of these inhibitors target nuclear shuttling, DNA binding and downstream targets of NF- $\mathrm{KB}$, which could be applied similarly for inhibition of NFAT in a clinical setting. It 
may therefore be possible to target nuclear import/export kinases, targets of NFAT and/or transcriptional partners of NFAT, but further evidence is needed.

Given that NFAT has roles in a number of immune cells, the effect(s) of NFAT inhibition on the wider AML microenvironment must also be considered. T cell-driven immune surveillance is a major defence against the development of cancers, including leukaemia. Often, the interface between AML blasts and T cells within the bone marrow microenvironment is distorted in such a way that allows the AML cells to escape immune recognition [81]. In vitro studies have demonstrated that either the AML cell supernatant or direct AML cell contact suppresses T cell activation, via NFAT signalling specifically $[82,83]$. If suppressed NFAT signalling in T cells is permissive of AML immune evasion, then significant caution should be taken when developing global NFAT inhibition as a means of therapy. This further stresses the need to elucidate the contribution of differing NFAT family members to each of the biological processes relevant in AML development, to allow for more targeted therapies to be developed.

\section{Conclusions}

At present, there is intriguing evidence to implicate NFAT proteins in AML. By looking at their roles in normal myeloid physiology and in other types of cancer, it is conceivable that NFAT regulates the transcription of key cell cycle and/or differentiation programs in leukemogenesis. Furthermore, NFAT has been observed to play a role in resistance to TKIs in myeloid leukaemia and may mediate patient relapse. However, it is still to be ascertained whether NFAT is important in the context of some mutational profiles-as with FLT3 ${ }^{\text {ITD }}$-or if its oncogenic properties are applicable across numerous AML subtypes. Further characterisation of individual NFATs is essential to understanding these roles and may elucidate more specific targets. If NFAT inhibitors continue to be developed for more clinical applications, the NFAT family of transcription factors may become a viable treatment target in AML.

Author Contributions: Conceptualisation, S.D.P. and X.H.; software S.D.P.; formal analysis, S.D.P.; investigation, S.D.P.; resources, S.D.P. and X.H.; data curation, S.D.P.; writing-original draft preparation, S.D.P.; writing—review and editing, S.D.P., A.M.M., H.G.J. and X.H.; visualisation, S.D.P.; supervision, A.M.M., H.G.J. and X.H.; funding acquisition, X.H. All authors have read and agreed to the published version of the manuscript.

Funding: This research was funded by The Carnegie Trust for the Universities of Scotland, PhD scholarship number PHD007721.

Institutional Review Board Statement: Not applicable.

Informed Consent Statement: Not applicable.

Data Availability Statement: The data presented in this review are openly available in: Array Express at https://www.ebi.ac.uk/arrayexpress/experiments/E-GEOD-51984/ (accessed on 17 June 2021); Gene Expression Omnibus [GSE83533] at https:/ /www.ncbi.nlm.nih.gov/geo/query/ acc.cgi?acc=GSE83533 (accessed on 17 June 2021); the Cancer Genome Atlas [TCGA-LAML] at https:/ / portal.gdc.cancer.gov / repository (accessed on 3 June 2020).

Conflicts of Interest: The authors declare no conflict of interest. 


\section{Appendix A. FAB Classification of AML}

$\begin{array}{cc}\text { FAB Classification } & \text { Description } \\ \text { M0 } & \text { Minimally differentiated AML } \\ \text { M1 } & \text { Myeloid leukaemia (without maturation) } \\ \text { M2 } & \text { Myeloid leukaemia (with maturation) } \\ \text { M3 } & \text { Acute progranulocytic leukaemia } \\ \text { M4 } & \text { Myelomonocytic leukaemia } \\ \text { M5 } & \text { Monocytic leukaemia } \\ \text { M6 } & \text { Erythroid leukaemia } \\ \text { M7 } & \text { Megakaryocytic leukaemia }\end{array}$

Table showing the description of each FAB category [43].

\section{Abbreviations}

$\begin{array}{ll}\text { APL } & \text { Acute Promyelocytic Leukaemia } \\ \text { AML } & \text { Acute Myeloid Leukaemia } \\ \text { CAMK } & \text { Calmodulin Kinase } \\ \text { CML } & \text { Chronic Myeloid Leukaemia } \\ \text { CNBR } & \text { Calcineurin-Binding Region } \\ \text { CsA } & \text { Cyclosporine A } \\ \text { DC } & \text { Dendritic Cell } \\ \text { FAB Classification } & \text { French-American-British Classification } \\ \text { FLT3 } & \text { Fms-related tyrosine kinase receptor 3 } \\ \text { FLT3 } & \text { FLT3 Internal Tandem Duplication } \\ \text { FLT3-L } & \text { FLT3 Ligand } \\ \text { G-CSF } & \text { Granulocyte Colony-Stimulating Factor } \\ \text { GMP } & \text { Granulocyte-Monocyte Progenitor } \\ \text { HSC } & \text { Hematopoietic Stem Cell } \\ \text { LSC } & \text { Leukemic Stem Cell } \\ \text { M-CSF } & \text { Macrophage Colony-Stimulating Factor } \\ \text { NFAT } & \text { Nuclear Factor of Activated T Cells } \\ \text { NHD } & \text { NFAT Homology Domain } \\ \text { Pgp } & \text { P-glycoprotein } \\ \text { PLC } & \text { Phospholipase C } \\ \text { PML } & \text { Promyelocytic Leukaemia } \\ \text { PRR } & \text { Pattern Recognition Receptor } \\ \text { SOCE } & \text { Trore-Operated Calcium Entry } \\ \text { TAD } & \text { Tyrosine Kinase Inhibitor } \\ \text { TKI } & \end{array}$

\section{References}

1. Network, H.M.R. Survival: Acute Myeloid Leukaemia. Available online: https://www.hmrn.org/statistics/survival (accessed on 16 January 2021).

2. De Kouchkovsky, I.; Abdul-Hay, M. 'Acute myeloid leukemia: A comprehensive review and 2016 update'. Blood Cancer J. 2016, 6, e441. [CrossRef]

3. Kantarjian, H.; Kadia, T.; DiNardo, C.; Daver, N.; Borthakur, G.; Jabbour, E.; Garcia-Manero, G.; Konopleva, M.; Ravandi, F. Acute myeloid leukemia: Current progress and future directions. Blood Cancer J. 2021, 11, 41. [CrossRef] [PubMed]

4. Morita, K.; Wang, F.; Jahn, K.; Hu, T.; Tanaka, T.; Sasaki, Y.; Kuipers, J.; Loghavi, S.; Wang, S.A.; Yan, Y.; et al. Clonal evolution of acute myeloid leukemia revealed by high-throughput single-cell genomics. Nat. Commun. 2020, 11, 5327. [CrossRef]

5. Tyner, J.W.; Tognon, C.E.; Bottomly, D.; Wilmot, B.; Kurtz, S.E.; Savage, S.L.; Long, N.; Schultz, A.R.; Traer, E.; Abel, M.; et al. Functional genomic landscape of acute myeloid leukaemia. Nature 2018, 562, 526-531. [CrossRef]

6. Ishikawa, F.; Yoshida, S.; Saito, Y.; Hijikata, A.; Kitamura, H.; Tanaka, S.; Nakamura, R.; Tanaka, T.; Tomiyama, H.; Saito, N.; et al. Chemotherapy-resistant human AML stem cells home to and engraft within the bone-marrow endosteal region. Nat. Biotechnol. 2007, 25, 1315-1321. [CrossRef] [PubMed]

7. Pollyea, D.A.; Jordan, C.T. Therapeutic targeting of acute myeloid leukemia stem cells. Blood 2017, 129, 1627. [CrossRef]

8. Jordan, C.T. The leukemic stem cell. Best Prac. Res. Clin. Haematol. 2007, 20, 13-18. [CrossRef] 
9. Docking, T.R.; Parker, J.D.K.; Jädersten, M.; Duns, G.; Chang, L.; Jiang, J.; Pilsworth, J.A.; Swanson, L.A.; Chan, S.K.; Chiu, R.; et al. A clinical transcriptome approach to patient stratification and therapy selection in acute myeloid leukemia. Nat. Commun. 2021, 12, 2474. [CrossRef]

10. Ng, S.W.K.; Mitchell, A.; Kennedy, J.A.; Chen, W.C.; McLeod, J.; Ibrahimova, N.; Arruda, A.; Popescu, A.; Gupta, V.; Schimmer, A.D.; et al. A 17-gene stemness score for rapid determination of risk in acute leukaemia. Nature 2016, 540, 433-437. [CrossRef] [PubMed]

11. Massett, M.E.; Monaghan, L.; Patterson, S.; Mannion, N.; Bunschoten, R.P.; Hoose, A.; Marmiroli, S.; Liskamp, R.M.J.; Jørgensen, H.G.; Vetrie, D.; et al. A KDM4A-PAF1-mediated epigenomic network is essential for acute myeloid leukemia cell self-renewal and survival. Cell Death Dis. 2021, 12, 573. [CrossRef]

12. Gentles, A.J.; Plevritis, S.K.; Majeti, R.; Alizadeh, A.A. Association of a leukemic stem cell gene expression signature with clinical outcomes in acute myeloid leukemia. JAMA 2010, 304, 2706-2715. [CrossRef]

13. Darnell, J.E. Transcription factors as targets for cancer therapy. Nat. Rev. Cancer 2002, 2, 740-749. [CrossRef]

14. Takei, H.; Kobayashi, S.S. Targeting transcription factors in acute myeloid leukemia. Int. J. Hematol. 2019, 109, 28-34. [CrossRef] [PubMed]

15. Metzelder, S.K.; Michel, C.; von Bonin, M.; Rehberger, M.; Hessmann, E.; Inselmann, S.; Solovey, M.; Wang, Y.; Sohlbach, K.; Brendel, C.; et al. NFATc1 as a therapeutic target in FLT3-ITD-positive AML. Leukemia 2015, 29, 1470. [CrossRef] [PubMed]

16. Gregory, M.A.; Phang, T.L.; Neviani, P.; Alvarez-Calderon, F.; Eide, C.A.; O’Hare, T.; Zaberezhnyy, V.; Williams, R.T.; Druker, B.J.; Perrotti, D.; et al. Wnt/Ca ${ }^{2+} / \mathrm{NFAT}$ signaling maintains survival of $\mathrm{Ph}^{+}$leukemia cells upon inhibition of Bcr-Abl. Cancer Cell 2010, 18, 74-87. [CrossRef] [PubMed]

17. Fric, J.; Zelante, T.; Wong, A.Y.W.; Mertes, A.; Yu, H.-B.; Ricciardi-Castagnoli, P. NFAT control of innate immunity. Blood 2012, 120, 1380. [CrossRef]

18. Qin, J.-J.; Nag, S.; Wang, W.; Zhou, J.; Zhang, W.-D.; Wang, H.; Zhang, R. NFAT as cancer target: Mission possible? Biochim. Et Biophys. Acta 2014, 1846, 297-311. [CrossRef]

19. Mancini, M.; Toker, A. NFAT Proteins: Emerging Roles in Cancer Progression. Nat. Rev. Cancer 2009, 9, 810-820. [CrossRef]

20. Mognol, G.P.; Carneiro, F.R.G.; Robbs, B.K.; Faget, D.V.; Viola, J.P.B. Cell cycle and apoptosis regulation by NFAT transcription factors: New roles for an old player. Cell Death Dis. 2016, 7, e2199. [CrossRef]

21. Macián, F.; López-Rodríguez, C.; Rao, A. Partners in transcription: NFAT and AP-1. Oncogene 2001, 20, 2476-2489. [CrossRef]

22. Macian, F. NFAT proteins: Key regulators of T-cell development and function. Nat. Rev. Immunol. 2005, 5, 472. [CrossRef] [PubMed]

23. Rao, A.; Luo, C.; Hogan, P.G. TRANSCRIPTION FACTORS OF THE NFAT FAMILY: Regulation and Function. Annu. Rev. Immunol. 1997, 15, 707-747. [CrossRef] [PubMed]

24. Vihma, H.; Pruunsild, P.; Timmusk, T. Alternative splicing and expression of human and mouse NFAT genes. Genomics 2008, 92, 279-291. [CrossRef]

25. Graef, I.A.; Gastier, J.M.; Francke, U.; Crabtree, G.R. Evolutionary relationships among Rel domains indicate functional diversification by recombination. Proc. Natl. Acad. Sci. USA 2001, 98, 5740. [CrossRef] [PubMed]

26. Hogan, P.G.; Chen, L.; Nardone, J.; Rao, A. Transcriptional regulation by calcium, calcineurin, and NFAT. Genes Dev. 2003, 17, 2205-2232. [CrossRef] [PubMed]

27. Kitamura, N.; Kaminuma, O. Isoform-Selective NFAT Inhibitor: Potential Usefulness and Development. Int. J. Mol. Sci. 2021, 22, 2725. [CrossRef] [PubMed]

28. Gwack, Y.; Feske, S.; Srikanth, S.; Hogan, P.G.; Rao, A. Signalling to transcription: Store-operated Ca ${ }^{2+}$ entry and NFAT activation in lymphocytes. Cell Calcium 2007, 42, 145-156. [CrossRef] [PubMed]

29. Villar, M.; Ortega-Pérez, I.; Were, F.; Cano, E.; Redondo, J.M.; Vázquez, J. Systematic characterization of phosphorylation sites in NFATc2 by linear ion trap mass spectrometry. Proteomics 2006, 6 (Suppl. 1), S16-S27. [CrossRef]

30. Leung-Theung-Long, S.; Mondor, I.; Guiraud, M.; Lamare, C.; Nageleekar, V.; Paulet, P.-E.; Rincon, M.; Guerder, S. Impaired NFAT Transcriptional Activity in Antigen-Stimulated CD8 T Cells Linked to Defective Phosphorylation of NFAT Transactivation Domain. J. Immunol. 2009, 182, 6807. [CrossRef]

31. Badran, B.M.; Wolinsky, S.M.; Burny, A.; Willard-Gallo, K.E. Identification of Three NFAT Binding Motifs in the 5'-Upstream Region of the Human CD3 $\gamma$ Gene That Differentially Bind NFATc1, NFATc2, and NF-kB p50. J. Biol. Chem. 2002, $277,47136-47148$. [CrossRef]

32. Chen, L.; Glover, J.N.M.; Hogan, P.G.; Rao, A.; Harrison, S.C. Structure of the DNA-binding domains from NFAT, Fos and Jun bound specifically to DNA. Nature 1998, 392, 42-48. [CrossRef]

33. Gabriel, C.H.; Gross, F.; Karl, M.; Stephanowitz, H.; Hennig, A.F.; Weber, M.; Gryzik, S.; Bachmann, I.; Hecklau, K.; Wienands, J.; et al. Identification of Novel Nuclear Factor of Activated T Cell (NFAT)-associated Proteins in T Cells. J. Biol. Chem. 2016, 291, 24172-24187. [CrossRef]

34. Bierer, B.E.; Holländer, G.; Fruman, D.; Burakoff, S.J. Cyclosporin A and FK506: Molecular mechanisms of immunosuppression and probes for transplantation biology. Curr. Opin. Immunol. 1993, 5, 763-773. [CrossRef]

35. Li, H.; Rao, A.; Hogan, P.G. Interaction of calcineurin with substrates and targeting proteins. Trends Cell Biol. 2011, 21, 91-103. [CrossRef] 
36. Aramburu, J.; Yaffe, M.B.; López-Rodrí́guez, C.; Cantley, L.C.; Hogan, P.G.; Rao, A. Affinity-Driven Peptide Selection of an NFAT Inhibitor More Selective Than Cyclosporin A. Science 1999, 285, 2129. [CrossRef]

37. Kiani, A.; Habermann, I.; Haase, M.; Feldmann, S.; Boxberger, S.; Sanchez-Fernandez, M.A.; Thiede, C.; Bornhäuser, M.; Ehninger G. Expression and regulation of NFAT (nuclear factors of activated T cells) in human CD34 ${ }^{+}$cells: Down-regulation upon myeloid differentiation. J. Leukoc. Biol. 2004, 76, 1057-1065. [CrossRef] [PubMed]

38. Kiani, A.; Kuithan, H.; Kuithan, F.; Kyttälä, S.; Habermann, I.; Temme, A.; Bornhäuser, M.; Ehninger, G. Expression analysis of nuclear factor of activated T cells (NFAT) during myeloid differentiation of CD34 ${ }^{+}$cells: Regulation of Fas ligand gene expression in megakaryocytes. Exp. Hematol. 2007, 35, 757-770. [CrossRef] [PubMed]

39. Pabst, C.; Bergeron, A.; Lavallée, V.-P.; Yeh, J.; Gendron, P.; Norddahl, G.L.; Krosl, J.; Boivin, I.; Deneault, E.; Simard, J.; et al. GPR56 identifies primary human acute myeloid leukemia cells with high repopulating potential in vivo. Blood 2016, 127, $2018-2027$. [CrossRef]

40. Ley, T.J.; Miller, C.; Ding, L.; Raphael, B.J.; Mungall, A.J.; Robertson, A.; Hoadley, K.; Triche, T.J., Jr.; Laird, P.W.; Baty, J.D.; et al. Genomic and epigenomic landscapes of adult de novo acute myeloid leukemia. N. Engl. J. Med. 2013, 368, 2059-2074. [CrossRef] [PubMed]

41. Li, B.; Dewey, C.N. RSEM: Accurate transcript quantification from RNA-Seq data with or without a reference genome. BMC Bioinform. 2011, 12, 323. [CrossRef]

42. Olsson, I.; Bergh, G.; Ehinger, M.; Gullberg, U. Cell differentiation in acute myeloid leukemia. Eur. J. Haematol. 1996, 57, 1-16. [CrossRef]

43. Schiffer, C.A.; Stone, R.M. Morphologic Classification and Clinical and Laboratory Correlates. In Holland-Frei Cancer Medicine, 6th ed.; Kufe, D.W., Pollock, P.E., Weichselbaum, R.R., Bast, R.C., Jr., Gansler, T.S., Holland, J.F., Frei, E., III, Eds.; BC Decker: Hamilton, ON, USA, 2003.

44. Fric, J.; Lim, C.X.F.; Mertes, A.; Lee, B.T.K.; Viganò, E.; Chen, J.; Zolezzi, F.; Poidinger, M.; Larbi, A.; Strobl, H.; et al. Calcium and calcineurin-NFAT signaling regulate granulocyte-monocyte progenitor cell cycle via Flt3-L. Stem Cells 2014, 32, 3232-3244. [CrossRef] [PubMed]

45. Fric, J.; Lim, C.X.F.; Koh, E.G.L.; Hofmann, B.; Chen, J.; Tay, H.S.; Mohammad Isa, S.A.B.; Mortellaro, A.; Ruedl, C.; RicciardiCastagnoli, P. Calcineurin/NFAT signalling inhibits myeloid haematopoiesis. EMBO Mol. Med. 2012, 4, 269-282. [CrossRef] [PubMed]

46. Barbosa, C.M.; Bincoletto, C.; Barros, C.C.; Ferreira, A.T.; Paredes-Gamero, E.J. PLC $\gamma 2$ and PKC are important to myeloid lineage commitment triggered by M-SCF and G-CSF. J. Cell Biochem. 2014, 115, 42-51. [CrossRef]

47. Bendickova, K.; Tidu, F.; Fric, J. Calcineurin-NFAT signalling in myeloid leucocytes: New prospects and pitfalls in immunosuppressive therapy. EMBO Mol. Med. 2017, 9, 990-999. [CrossRef] [PubMed]

48. Elloumi, H.Z.; Maharshak, N.; Rao, K.N.; Kobayashi, T.; Ryu, H.S.; Mühlbauer, M.; Li, F.; Jobin, C.; Plevy, S.E. A cell permeable peptide inhibitor of NFAT inhibits macrophage cytokine expression and ameliorates experimental colitis. PLoS ONE 2012, 7, e34172. [CrossRef]

49. Yu, H.-B.; Yurieva, M.; Balachander, A.; Foo, I.; Leong, X.; Zelante, T.; Zolezzi, F.; Poidinger, M.; Ricciardi-Castagnoli, P. NFATc2 mediates epigenetic modification of dendritic cell cytokine and chemokine responses to dectin-1 stimulation. Nucleic Acids Res. 2014, 43, 836-847. [CrossRef]

50. Monlish, D.A.; Bhatt, S.T.; Schuettpelz, L.G. The Role of Toll-Like Receptors in Hematopoietic Malignancies. Front. Immunol. 2016, 7, 390. [CrossRef]

51. Rybka, J.; Butrym, A.; Wróbel, T.; Jaźwiec, B.; Stefanko, E.; Dobrzyńska, O.; Poręba, R.; Kuliczkowski, K. The expression of Toll-like receptors in patients with acute myeloid leukemia treated with induction chemotherapy. Leuk. Res. 2015, 39, 318-322. [CrossRef]

52. Lagunas-Rangel, F.A.; Chávez-Valencia, V. FLT3-ITD and its current role in acute myeloid leukaemia. Med. Oncol. 2017, 34, 114. [CrossRef]

53. Chan, P.M. Differential signaling of Flt3 activating mutations in acute myeloid leukemia: A working model. Protein Cell 2011, 2 , 108-115. [CrossRef]

54. Solovey, M.; Wang, Y.; Michel, C.; Metzeler, K.H.; Herold, T.; Göthert, J.R.; Ellenrieder, V.; Hessmann, E.; Gattenlöhner, S.; Neubauer, A.; et al. Nuclear factor of activated T-cells, NFATC1, governs FLT3(ITD)-driven hematopoietic stem cell transformation and a poor prognosis in AML. J. Hematol. Oncol. 2019, 12, 72. [CrossRef]

55. Kelly, L.M.; Liu, Q.; Kutok, J.L.; Williams, I.R.; Boulton, C.L.; Gilliland, D.G. FLT3 internal tandem duplication mutations associated with human acute myeloid leukemias induce myeloproliferative disease in a murine bone marrow transplant model. Blood 2002, 99, 310. [CrossRef]

56. Rocnik, J.L.; Okabe, R.; Yu, J.-C.; Lee, B.H.; Giese, N.; Schenkein, D.P.; Gilliland, D.G. Roles of tyrosine 589 and 591 in STAT5 activation and transformation mediated by FLT3-ITD. Blood 2006, 108, 1339-1345. [CrossRef]

57. Levis, M.; Small, D. FLT3: ITDoes matter in leukemia. Leukemia 2003, 17, 1738. [CrossRef]

58. Fathi, A.T.; Chen, Y.-B. Treatment of FLT3-ITD acute myeloid leukemia. Am. J. Blood Res. 2011, 1, $175-189$.

59. Valent, P. Imatinib-resistant chronic myeloid leukemia (CML): Current concepts on pathogenesis and new emerging pharmacologic approaches. Biologics 2007, 1, 433-448. [PubMed] 
60. Sung, P.J.; Sugita, M.; Koblish, H.; Perl, A.E.; Carroll, M. Hematopoietic cytokines mediate resistance to targeted therapy in FLT3-ITD acute myeloid leukemia. Blood Adv. 2019, 3, 1061-1072. [CrossRef] [PubMed]

61. Yeung, C.C.S.; Radich, J. Predicting Chemotherapy Resistance in AML. Curr. Hematol. Malig. Rep. 2017, 12, 530-536. [CrossRef] [PubMed]

62. Li, S.; Garrett-Bakelman, F.E.; Chung, S.S.; Sanders, M.A.; Hricik, T.; Rapaport, F.; Patel, J.; Dillon, R.; Vijay, P.; Brown, A.L.; et al. Distinct evolution and dynamics of epigenetic and genetic heterogeneity in acute myeloid leukemia. Nat. Med. 2016, 22, 792-799. [CrossRef]

63. van Gils, N.; Denkers, F.; Smit, L. Escape From Treatment; the Different Faces of Leukemic Stem Cells and Therapy Resistance in Acute Myeloid Leukemia. Front. Oncol. 2021, 11, 1454. [CrossRef] [PubMed]

64. Behrens, K.; Maul, K.; Tekin, N.; Kriebitzsch, N.; Indenbirken, D.; Prassolov, V.; Müller, U.; Serve, H.; Cammenga, J.; Stocking, C. RUNX1 cooperates with FLT3-ITD to induce leukemia. J. Exp. Med. 2017, 214, 737-752. [CrossRef]

65. Sood, R.; Kamikubo, Y.; Liu, P. Role of RUNX1 in hematological malignancies. Blood 2017, 129, 2070-2082. [CrossRef] [PubMed]

66. Masuda, T.; Kubota, H.; Sakuramoto, N.; Hada, A.; Horiuchi, A.; Sasaki, A.; Takeda, K.; Takeda, M.; Matsuo, H.; Sugiyama, H.; et al. RUNX-NFAT Axis As a Novel Therapeutic Target for AML and T Cell Immunity. Blood 2020, 136, 25-26. [CrossRef]

67. Lo, Y.H.; Wu, C.C.; Shih, H.M.; Lai, M.Z. Selective activation of NFAT by promyelocytic leukemia protein. Oncogene $2008,27,3821$. [CrossRef]

68. Mu, Z.M.; Chin, K.V.; Liu, J.H.; Lozano, G.; Chang, K.S. PML, a growth suppressor disrupted in acute promyelocytic leukemia. Mol. Cell Biol. 1994, 14, 6858-6867. [CrossRef] [PubMed]

69. Takahashi, S. Identification of Flt3 internal tandem duplications downstream targets by high-throughput immunoblotting protein array system. Am. J. Hematol. 2006, 81, 717-719. [CrossRef]

70. Ptasinska, A.; Pickin, A.; Assi, S.A.; Chin, P.S.; Ames, L.; Avellino, R.; Gröschel, S.; Delwel, R.; Cockerill, P.N.; Osborne, C.S.; et al RUNX1-ETO Depletion in $\mathrm{t}(8 ; 21)$ AML Leads to $\mathrm{C} / \mathrm{EBP} \alpha$ - and AP-1-Mediated Alterations in Enhancer-Promoter Interaction. Cell Rep. 2019, 28, 3022-3031.e3027. [CrossRef]

71. Paz-Priel, I.; Friedman, A. C/EBP $\alpha$ dysregulation in AML and ALL. Crit. Rev. Oncog. 2011, 16, 93-102. [CrossRef]

72. Tedesco, D.; Haragsim, L. Cyclosporine: A review. J. Transpl. 2012, 2012, 230386. [CrossRef]

73. Klintmalm, G. A review of FK506: A new immunosuppressant agent for the prevention and rescue of graft rejection. Transplant. Rev. 1994, 8, 53-63. [CrossRef]

74. Spiekerkoetter, E.; Sung, Y.K.; Sudheendra, D.; Scott, V.; Del Rosario, P.; Bill, M.; Haddad, F.; Long-Boyle, J.; Hedlin, H.; Zamanian, R.T. Randomised placebo-controlled safety and tolerability trial of FK506 (tacrolimus) for pulmonary arterial hypertension. Eur. Respir. J. 2017, 50, 1602449. [CrossRef]

75. List, A.F.; Kopecky, K.J.; Willman, C.L.; Head, D.R.; Persons, D.L.; Slovak, M.L.; Dorr, R.; Karanes, C.; Hynes, H.E.; Doroshow, J.H.; et al. Benefit of cyclosporine modulation of drug resistance in patients with poor-risk acute myeloid leukemia: A Southwest Oncology Group study. Blood 2001, 98, 3212-3220. [CrossRef]

76. Noguchi, H.; Matsushita, M.; Okitsu, T.; Moriwaki, A.; Tomizawa, K.; Kang, S.; Li, S.-T.; Kobayashi, N.; Matsumoto, S.; Tanaka, K.; et al. A new cell-permeable peptide allows successful allogeneic islet transplantation in mice. Nat. Med. 2004, 10, 305-309. [CrossRef]

77. Yu, H.; Van Berkel, T.J.C.; Biessen, E.A.L. Therapeutic Potential of VIVIT, a Selective Peptide Inhibitor of Nuclear Factor of Activated T cells, in Cardiovascular Disorders. Cardiovasc. Drug Rev. 2007, 25, 175-187. [CrossRef]

78. Román, J.; de Arriba, A.F.; Barrón, S.; Michelena, P.; Giral, M.; Merlos, M.; Bailón, E.; Comalada, M.; Gálvez, J.; Zarzuelo, A.; et al. UR-1505, a new salicylate, blocks T cell activation through nuclear factor of activated T cells. Mol. Pharm. 2007, 72, 269-279. [CrossRef]

79. Vives, R.; Pontes, C.; Sarasa, M.; Millier, A. Safety and Activity of UR-1505 in Atopic Dermatitis: A Randomized, Double-blind Phase II Exploratory Trial. Clin. Ther. 2015, 37, 1955-1965. [CrossRef]

80. Ramadass, V.; Vaiyapuri, T.; Tergaonkar, V. Small Molecule NF-kB Pathway Inhibitors in Clinic. Int. J. Mol. Sci. 2020, 21, 5164. [CrossRef]

81. Vago, L.; Gojo, I. Immune escape and immunotherapy of acute myeloid leukemia. J. Clin. Investig. 2020, 130, 1552-1564. [CrossRef]

82. Buggins, A.G.S.; Milojkovic, D.; Arno, M.J.; Lea, N.C.; Mufti, G.J.; Thomas, N.S.B.; Hirst, W.J.R. Microenvironment Produced by Acute Myeloid Leukemia Cells Prevents T Cell Activation and Proliferation by Inhibition of NF- $\mathrm{B}$, c-Myc, and pRb Pathways. J. Immunol. 2001, 167, 6021-6030. [CrossRef]

83. van Galen, P.; Hovestadt, V.; Wadsworth Ii, M.H.; Hughes, T.K.; Griffin, G.K.; Battaglia, S.; Verga, J.A.; Stephansky, J.; Pastika, T.J.; Lombardi Story, J.; et al. Single-Cell RNA-Seq Reveals AML Hierarchies Relevant to Disease Progression and Immunity. Cell 2019, 176, 1265-1281.e1224. [CrossRef] [PubMed] 